\title{
Multiple Response Optimization of TIG Welding Process for Optimum Weld Bead Width and Reinforcement Height of Ti-Alloy (Ti-6al-4v)
}

\author{
Debashis Mishra ${ }^{1}$, Maneiah. Dakkilli ${ }^{2}$, L. Mangesh ${ }^{3}$, Dr. K. Prahlada Rao ${ }^{4}$ \\ ${ }^{1}$ Assistant Professor, Dept. of Mechanical Engineering, CMR Technical Campus/(JNTUH), India \\ ${ }^{2,3}$ Associate Professor, Dept. of Mechanical Engineering, CMR Technical Campus/(JNTUH), India \\ ${ }^{4}$ Professor, Dept. of Mechanical Engineering, JNTU Ananthpur, India
}

\begin{abstract}
The Titanium alloy (Ti-6Al-4V) is recognized for its distinctive characteristics such as high strength to weight ratio, low density, and excellent elevated temperature properties up to $600{ }^{\circ} \mathrm{C}$. These structurally efficient metals are mostly accepted and frequently used for the manufacturing of critical high performance aircrafts, such as jet engines and other airframe, automobile components. Tungsten inert gas welding (TIG) is one of the mostly used arc welding process in various manufacturing industries. In this experiment response surface methodology has been adopted to evaluate the effects of the input variables (current and welding speed), on output responses (weld bead width and reinforcement height). The Relationship between these two responses is analyzed using the multiple response optimization technique named as desirability function. The outcome shall be beneficial in selecting suitable parameters of TIG welding of Titanium alloy (Ti-6Al-4V) to obtain the required shape of the weld bead from which quality of the weld can be accessed.
\end{abstract}

Keywords: Desirability function, Response Surface Methodology, TIG Welding, Titanium alloys (Ti-6Al-4V), Weld bead geometry

\section{Introduction}

The welding arc is defined as continuous and controlled electrical discharge through an ionized gas. Tungsten inert gas welding process (TIG) also called as gas tungsten arc welding (GTAW) is one of the widely used arc welding process that uses non consumable tungsten electrode to produce the weld. The shielding gas (argon) is used to avoid the atmospheric contaminations of the molten weld pool. A filler metal may be added only if required. The advantage of using this technique is the intense heat source which produces high quality welded joints in lesser defects. The other benefits of this welding technique lies with its economy, easy in handling in manual as well in automated condition and its potential capability towards the joining of various metals and their alloys of thinner sections of stainless steel, aluminum, copper, magnesium and sensitive material like Titanium and its alloys. A constant current AC and DC (straight or reverse polarity) welding power supply is generally used to produce the energy $[1,2]$. The (Ti-6Al-4V) is known as an alpha-beta titanium alloy. The elevated Strength-to-Density Ratio called high structural efficiency, low density (roughly half of the weight of steel, nickel and copper alloys) and excellent elevated temperature properties (up to $600^{\circ} \mathrm{C}$ ) made the Ti-6 Al$4 \mathrm{~V}$ titanium alloy most desirable material for the successful use in the manufacturing of the blades, gas turbine engines and airframe, automobile structures and other different components which demands high levels of accuracy and reliable performance. Statistical design of experiment is refers to the process of planning and conducting the experiment so that appropriate data can be collected and analyzed by statistical means to draw a meaningful conclusions from the experimental data by minimizing number of experiments. Response surface methodology is a collection of mathematical and statistical technique useful for the modeling and analysis of the problem in which a response of interest is influenced by several variables and the objective is to optimize the response and is to locate the optimum and desirable condition for the higher performance [3, 4]. The performance and quality of welded parts are deeply dependent upon the welding process parameters. The prime aim of many researchers is to identify the effects of the input variable on the output responses and also to identify the relation between the multiple responses. The relationships between the responses are quite common and a researcher has to identify which response is important to study. Thus optimization of welding process parameters to get desirable mechanical properties is a major motto of many researchers. Desirability function is one of the advanced techniques used for the simultaneous optimizations of several responses. Daniel $\mathrm{J}$. Obermiller "Multiple Response Optimization using JMP" in which different techniques of simultaneous optimization of several responses are evaluated and presented [5]. Kumar Kundan et al. used response surface methodology for predicting the output responses of TIG welding process in which two welding process 
parameters that is current and welding speed are optimized to evaluate different properties such as penetration, reinforcement height and weld bead width and to establish relationship between input parameters and output responses [7]. Kiaee N, Aghaie-Khafri M, Optimization of gas tungsten arc welding process by response surface methodology was reported in which effects of process parameters on tensile strength and hardness are evaluated [8]. Balasubramanian M. et al. presented effect of process parameters of pulsed current tungsten inert gas welding on weld pool geometry of titanium welds in which effects of pulsing current parameters on weld pool geometry has been studied and reported [9]. The TIG welding system setup and weld bead geometry is shown below in fig. number 1 . The weld bead width is defined as the maximum width of the weld metal deposited. And the reinforcement height is the maximum distance between the base metal level and the top point of the deposited metal. The weld bead width and reinforcement height is influenced by the welding input parameters like arc current, arc voltage and the arc travel speed. The weld bead geometry is specified by the terms like weld bead width, reinforcement and penetration [1].

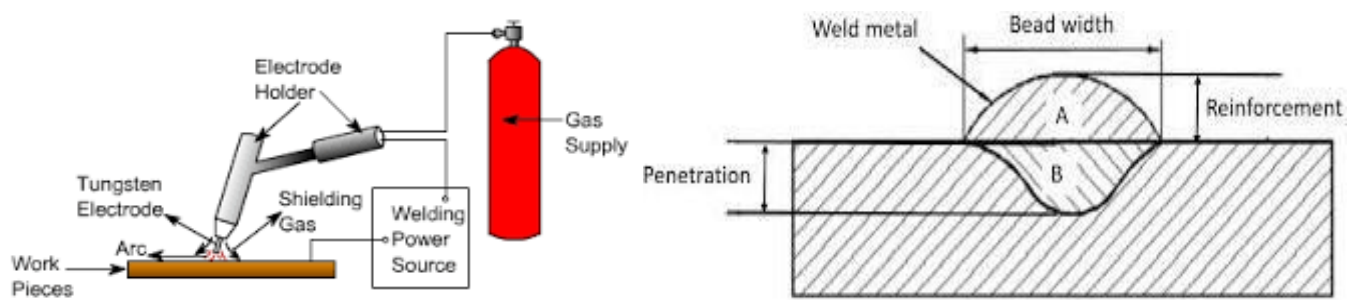

Fig. 1 TIG welding system setup \& weld bead geometry

II. Objective of the investigation

The main objective of this experiment is to realize the effects of the input variables such as current and welding speed on the responses; weld bead width and reinforcement height by obtaining a regression equation and to establish a relationship between them using multiple response optimization technique known as desirability function.

\subsection{Parent materials}

\section{Experimental details}

The materials chosen for this investigation is Titanium alloy (Ti-6Al-4V) of size $150 \times 150 \times 1.2(\mathrm{~mm})$. Two sheets of Titanium alloy (Ti-6Al-4V) is butt welded completely in a single pass by TIG welding process. The chemical compositions of Titanium alloy (Ti-6Al-4V) are given below in table 1.

Table 1 Chemical composition (wt \%) of Titanium (Ti-6Al-4V)

\begin{tabular}{|c|c|c|c|c|c|c|}
\hline $\mathbf{C}$ & $\mathbf{F e}$ & $\mathbf{O}$ & $\mathbf{N}$ & $\mathbf{A l}$ & $\mathbf{V}$ & $\mathbf{T i}$ \\
\hline 0.08 & 0.25 & 0.20 & 0.05 & $5.50-6.75$ & $3.5-4.5$ & Bal. \\
\hline
\end{tabular}

\subsection{TIG welding}

3.2.1 Pre welding cleaning: The sheets of Titanium alloy (Ti-6Al-4V) were polished on grinding wheel and then with emery paper to remove all the burrs from the surface of the materials. Then the Titanium sheets were vapour degreased for the removal of oil, grease if any from the surfaces. Finally the sheets were followed for acid pickling with $30 \%$ to $40 \%$ of Nitric acid and balanced with distilled water. Again prior to welding acetone cleaning is followed up carefully using a lint free cloth.

3.2.2 Tack Welding: With the help of an appropriate fixture two sheets of Titanium alloy (Ti-6Al-4V) were tightly clamped and then tack welded to avoid mismatch between the two sheets.

3.2.3 Welding procedures: The two sheets of Titanium alloy Ti-6Al-4V size $150 \times 150 \times 1.2(\mathrm{~mm})$ were square butt welded in a single pass by the Tungsten inert gas welding process. The high pure argon (99.9996\%) was used as shielding gas to prevent involvements of oxygen and other gases from the atmosphere. The filler metal of $1.2 \mathrm{~mm}$ thickness of Ti-6Al-4V was used. The $1.6 \mathrm{~mm}$ thoriated tungsten electrode was used to carry out the weld. Numbers of experimental trial welding with different combinations of the chosen parameters of TIG welding was carried out using $1.2 \mathrm{~mm}$ thick Ti-6Al-4V sheets to find out the feasible working limits. Twelve numbers of Tungsten inert gas welded coupons were prepared based upon the parameters designed by the JMP statistical software package 12 . The selected welding parameters are current and welding speed.

\subsection{Measurement of weld bead width}

The weld bead width and reinforcement height were measured manually using Mitutoyo Digimatic Vernier Caliper of least count $0.01 \mathrm{~mm}$. The 12 numbers of TIG welded sheets are shown below in fig. number 2. 


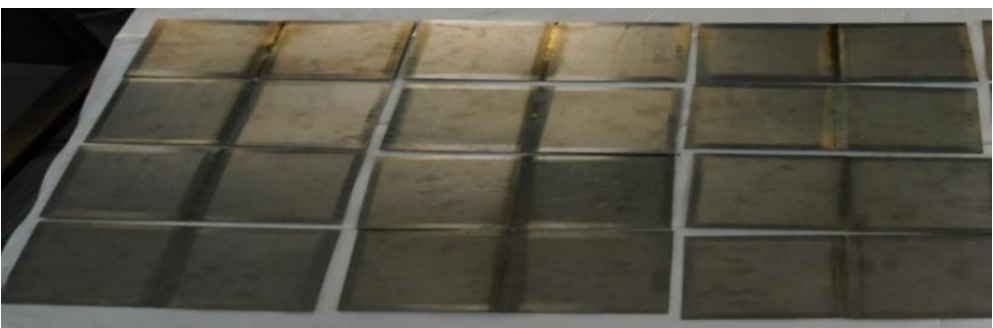

Fig. 2 The 12 numbers of TIG welded sheets

\subsection{Working limits of process parameters and analysis}

\section{Results and discussions}

A large number of trail runs were carried out using $1.2 \mathrm{~mm}$ thick rolled sheets of Titanium alloy Ti-6Al$4 \mathrm{~V}$ to find feasible working limits of TIG welding process input parameters.

Visual inspection of the weld bead width and re-inforcement height was inspected to identify the working limits of welding parameters, leading to the following observations. The observations obtained from the trial experiments are noted below.

1. If the current was less than 35Amps, then the incomplete penetration and lack of fusion was observed with slower welding speed which demanded high heat input in result the mechanical properties are seriously affected.

2. For the current more than 41Amps, undercut and spatter was observed because of the excess penetration caused by higher current and controlling the welding speed is a difficult task for the manual welding.

3. Slower welding speed below $100 \mathrm{~mm} / \mathrm{min}$ with the high current leads to the high heat input. For welding speed higher than $146 \mathrm{~mm} / \mathrm{min}$ there will be lack of fusion and lack of penetration observed with low current. High or low heat input causes defects in welding.

The upper and lower limits of the parameters were coded as +1.414 and -1.414 respectively. Two factors and at five levels of rotatable central composite design matrix was selected to design the experiment and response surface methodology was used for the optimization of input parameters to obtain favorable mechanical properties. The ranges of two selected input parameters and the 12 sets of coded experimental conditions developed using the JMP statistical software package 12 and the results are presented below in table 2 and 3 respectively.

Table 2 TIG welding process parameters \& their feasible working limits

\begin{tabular}{|c|c|c|c|c|c|c|}
\hline S. no. & Parameters & $\mathbf{- 1 . 4 1 4}$ & $\mathbf{- 1}$ & $\mathbf{0}$ & $\mathbf{1}$ & $\mathbf{1 . 4 1 4}$ \\
\hline 1 & Current (Amps) 'I' & 35 & 36 & 38 & 40 & 41 \\
\hline 2 & Welding speed (mm/min) 'S' & 104 & 110 & 125 & 140 & 146 \\
\hline
\end{tabular}

Table 3 Design matrix and experimental measured outputs

\begin{tabular}{|c|c|c|c|c|c|c|}
\hline S. no. & Current & $\begin{array}{c}\text { Welding } \\
\text { speed }\end{array}$ & $\begin{array}{c}\text { Current } \\
\text { (Amps) }\end{array}$ & $\begin{array}{c}\text { Welding speed } \\
\text { (mm/min) }\end{array}$ & $\begin{array}{c}\text { Weld bead } \\
\text { width (mm) }\end{array}$ & $\begin{array}{c}\text { Reinforcement } \\
\text { height (mm) }\end{array}$ \\
\hline 1 & -1 & -1 & 36 & 110 & 6.12 & 0.44 \\
\hline 2 & -1 & 1 & 36 & 140 & 5.97 & 0.34 \\
\hline 3 & 1 & -1 & 40 & 110 & 6.32 & 0.41 \\
\hline 4 & 1 & 1 & 40 & 140 & 6.11 & 0.44 \\
\hline 5 & -1.414 & 0 & 35 & 125 & 5.98 & 0.37 \\
\hline 6 & 1.414 & 0 & 41 & 125 & 6.29 & 0.43 \\
\hline 7 & 0 & -1.414 & 38 & 104 & 6.25 & 0.47 \\
\hline 8 & 0 & 1.414 & 38 & 146 & 6.05 & 0.38 \\
\hline 9 & 0 & 0 & 38 & 125 & 5.82 & 0.3 \\
\hline 10 & 0 & 0 & 38 & 125 & 5.85 & 0.28 \\
\hline 11 & -1 & -1 & 38 & 125 & 5.84 & 0.31 \\
\hline 12 & -1 & 1 & 38 & 125 & 5.8 & 0.28 \\
\hline
\end{tabular}

\subsection{Developing an empirical relationship}

In this study, the response function of the weld joint "F", are functions of current (I)Amps and welding speed (S) $\mathrm{mm} / \mathrm{min}$ and it can be expressed as:

$\mathrm{F}=f(\mathrm{I}, \mathrm{S})$

The second order polynomial (regression) equation that represents the response surface " $\mathrm{Y}$ " is: 
$Y=b_{0}+\sum b_{i} x_{i}+\sum b_{i i} x_{i}^{2}+\sum b_{i j} x_{i} x_{j}$

Considering the two input TIG welding parameters, the selected polynomial could be expressed as:

$\mathrm{Y}=b_{0}+b_{1}(I)+b_{2}(S)+b_{3}(I S)+b_{4}\left(I^{2}\right)+b_{5}\left(S^{2}\right)$

Where $b_{0}$ the average of all responses and $b_{i}, b_{i i}, b_{i j}$ are the coefficients and constant terms that depends upon the respective main and interaction effects of the parameters. In the present work, rotatable central composite design which accurately fits the second order response surface was used. All the coefficients were obtained by applying rotatable central composite design matrix using the JMP statistical software package 12 . The prediction or regression expression for weld bead width and reinforcement height is obtained as:

Weld bead width $=5.82+(0.094 *(($ Current -38$) / 2))+((-0.08) *(($ Weld speed -125$) / 15)))+((($ Current $38) / 2) *(($ Weld speed - 125) / 15) * -0.015) $+((($ Current - 38) / 2) * $(($ Current - 38) / 2) * 0.13) + (((Weld speed - 125) / 15)*((Weld speed - 125) / 15)*0.16)

Reinforcement height $=0.29+(0.018 *(($ Current -38$) / 2))+(-0.024 *(($ Weld speed -125$) / 15))+((($ Current $38) / 2) *(($ Weld speed - 125) / 15) * 0.0325) $+((($ Current - 38) / 2$) *(($ Current - 38) / 2$) * 0.047)+((($ Weld speed -125$) / 15) *(($ Weld speed -125$) / 15) * 0.067)$

\subsection{Adequacy of developed relationship}

The adequacy of the developed relationship is analyzed using the analysis of variance technique (ANOVA). It suggests that, if the calculated ' $\mathrm{F}$ ' ratio of the developed model is less than the standard ' $\mathrm{F}$ ' ratio (from F-table) at a desired level of confidence (95\%), then the model terms is adequate within the confidence limit. The adequate ANOVA test results for the responses weld bead width and reinforcement height are reported below. The various measures taken are; degrees of freedom, sum of squares, mean square, and ' $\mathrm{F}$ ' ratio. The ' $\mathrm{F}$ ' ratio is the ratio of the between group variation divided by the within group variation. The term which has values of 'Probability $>\mathrm{F}$ ' is less that 0.05 , the relationship term will be taken as significant term. And if 'Probability $>$ F' is greater than that of 0.05 indicates that the relationship term is insignificant. The summary of fit where R-Square also named as coefficient of multiple determination is calculated by taking the ratio of sum of squares (model) and sum of squares (C. total). An R-Square closer to 1 indicates better fit to the experimental data than does an R-Square closer to 0 . If the lack of fit is reported insignificant then it suggests that the model fits the data very well. The summary of fit, analysis of variance, lack of fit, effects test for the response models weld bead width and reinforcement height are given below in table from 4 to 10. Co-relation between the actual response and predicted response values for weld bead width and reinforcement height are presented in graph below in fig. number 3 .
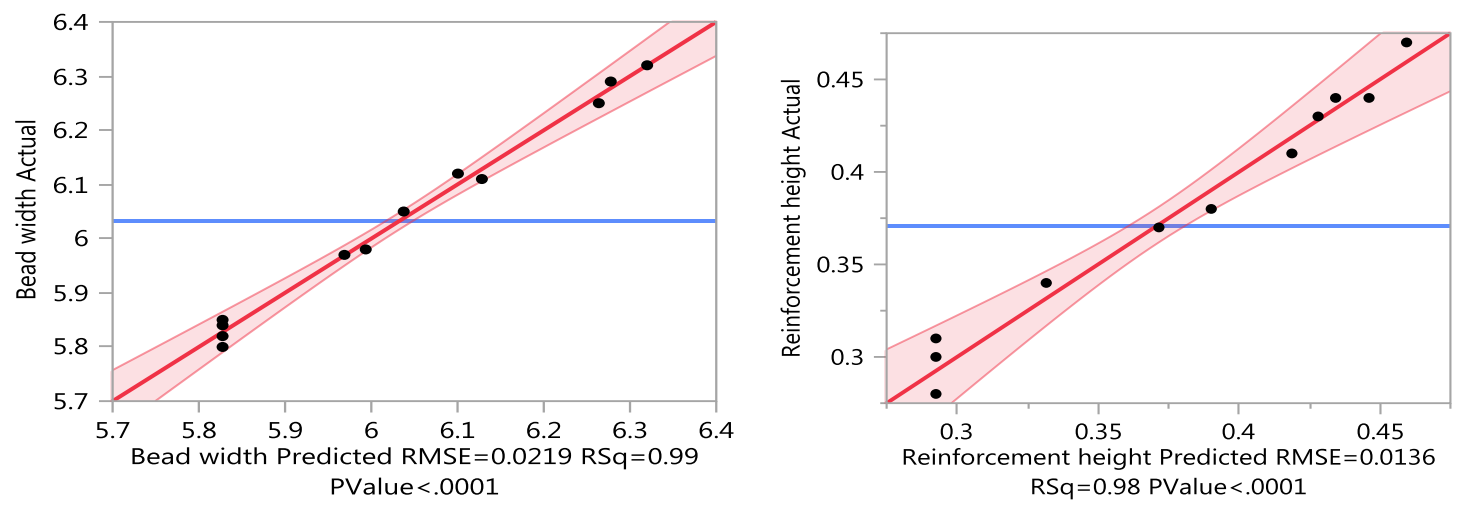

Fig. 3 Actual by predicted response co-relation graph

Table 4 Summary of fit for response models - bead width, reinforcement height

\begin{tabular}{|c|c|c|}
\hline Models & Weld Bead Width & Reinforcement Height \\
\hline RSquare & 0.99 & 0.97 \\
\hline RSquare Adjust & 0.98 & 0.95 \\
\hline Root mean square error & 0.021 & 0.013 \\
\hline Mean of response & 6.03 & 0.37 \\
\hline Observations & 12 & 12 \\
\hline
\end{tabular}


Multiple Response Optimization of TIG Welding Process for Optimum Weld Bead Width and ..

Table 5 Analysis of variance for the response model weld bead width

\begin{tabular}{|c|c|c|c|c|c|}
\hline Source & $\begin{array}{c}\text { Degrees of } \\
\text { Freedom }\end{array}$ & $\begin{array}{c}\text { Sum of } \\
\text { Squares }\end{array}$ & $\begin{array}{c}\text { Mean } \\
\text { Square }\end{array}$ & F Ratio & $\begin{array}{c}\text { Whether } \\
\text { significant or not }\end{array}$ \\
\hline Model & 5 & 0.3835 & 0.076 & 160.215 & \multirow{2}{*}{ Yes } \\
\hline Error & 6 & 0.0028 & 0.0004 & Prob $>$ F & \multirow{2}{*}{ Corrected total } \\
\hline
\end{tabular}

Table 6 Lack of Fit for the response model weld bead width

\begin{tabular}{|c|c|c|c|c|}
\hline Source & $\begin{array}{c}\text { Degrees of } \\
\text { Freedom }\end{array}$ & $\begin{array}{c}\text { Sum of } \\
\text { Squares }\end{array}$ & $\begin{array}{c}\text { Mean } \\
\text { Square }\end{array}$ & F Ratio \\
\hline Lack of Fit & 3 & 0.0013 & 0.00046 & 0.9478 \\
\hline Pure Error & 3 & 0.0014 & 0.00049 & Prob > F \\
\hline Total Error & 6 & 0.0028 & & $\mathbf{0 . 5 1 7 0}$ * (Insignificant) \\
\hline
\end{tabular}

Table 7 Effect Tests for the response model weld bead width

\begin{tabular}{|c|c|c|c|c|c|}
\hline Source & $\begin{array}{c}\text { Degrees of } \\
\text { Freedom }\end{array}$ & $\begin{array}{c}\text { Sum of } \\
\text { Squares }\end{array}$ & F Ratio & Prob > F & $\begin{array}{c}\text { Significant or } \\
\text { not }\end{array}$ \\
\hline Current $(36,40)$ & 1 & 0.0762 & 159.212 & $<.0001^{*}$ & Yes \\
\hline Weld speed $(110,140)$ & 1 & 0.0517 & 108.003 & $<.0001^{*}$ & Yes \\
\hline Current*Weld speed & 1 & 0.0009 & 1.8795 & 0.2195 & No \\
\hline Current*Current & 1 & 0.1444 & 301.56 & $<.0001^{*}$ & Yes \\
\hline Weld speed*Weld speed & 1 & 0.1668 & 348.34 & $<.0001 *$ & Yes \\
\hline
\end{tabular}

Table 8 Analysis of variance for the response model reinforcement height

\begin{tabular}{|c|c|c|c|c|c|}
\hline Source & $\begin{array}{c}\text { Degrees of } \\
\text { Freedom }\end{array}$ & $\begin{array}{c}\text { Sum of } \\
\text { Squares }\end{array}$ & Mean Square & F Ratio & $\begin{array}{c}\text { Significant or } \\
\text { not }\end{array}$ \\
\hline Model & 5 & 0.0495 & 0.0099 & 53.4526 & \\
\hline Error & 6 & 0.0011 & 0.00018 & Prob $>\mathrm{F}$ & Yes \\
\hline Corrected total & 11 & 0.0506 & & $<.0001 *$ & . \\
\hline
\end{tabular}

Table 9 Lack of Fit for the response model reinforcement height

\begin{tabular}{|c|c|c|c|c|}
\hline Source & Degrees of Freedom & Sum of Squares & Mean Square & F Ratio \\
\hline Lack of Fit & 3 & 0.00043 & 0.00014 & 0.6489 \\
\hline Pure Error & 3 & 0.00067 & 0.00022 & Prob $>$ F \\
\hline Total Error & 6 & 0.00111 & & $\mathbf{0 . 6 3 4 5}^{*}$ (Insignificant) \\
\hline
\end{tabular}

Table 10 Effect Tests for the response model reinforcement height

\begin{tabular}{|c|c|c|c|c|c|}
\hline Source & $\begin{array}{l}\text { Degrees of } \\
\text { Freedom }\end{array}$ & $\begin{array}{l}\text { Sum of } \\
\text { Squares }\end{array}$ & F Ratio & Prob > F & $\begin{array}{c}\text { Significant or } \\
\text { not }\end{array}$ \\
\hline Current (36, 40) & 1 & 0.00301 & 16.2355 & $0.0069^{*}$ & Yes \\
\hline Weld speed (110,140) & 1 & 0.00485 & 26.1475 & $0.0022^{*}$ & Yes \\
\hline Current*Weld speed & 1 & 0.00422 & 22.7756 & 0.0031 & Yes \\
\hline Current*Current & 1 & 0.01752 & 94.49 & $<.0001^{*}$ & Yes \\
\hline Weld speed*Weld speed & 1 & 0.02796 & 150.72 & $<.0001^{*}$ & Yes \\
\hline
\end{tabular}

\subsection{Optimization of the TIG welding process}

The response surface methodology is an optimization technique used for the optimization of welding process parameters to achieve desired size of weld bead width and reinforcement height. The contour plots and response surface plots of weld bead width and reinforcement height has been generated and plotted below to indicate the optimum condition using JMP statistical software package 12.

\subsubsection{Contour plot reports}

The contour plots are topographical images used for the establishing of the desirable response values and operating condition in a rectangular co-ordinate system. The contour plot describes how a response variable relates to the two process variables considering the obtained regression equation. The contour plots displays the two dimensional relationship in two dimensions, with factors current and welding speed plotted in $\mathrm{X}$ and $\mathrm{Y}$ axis and response values weld bead width and reinforcement height represented by contours shown in fig. number 4 . 


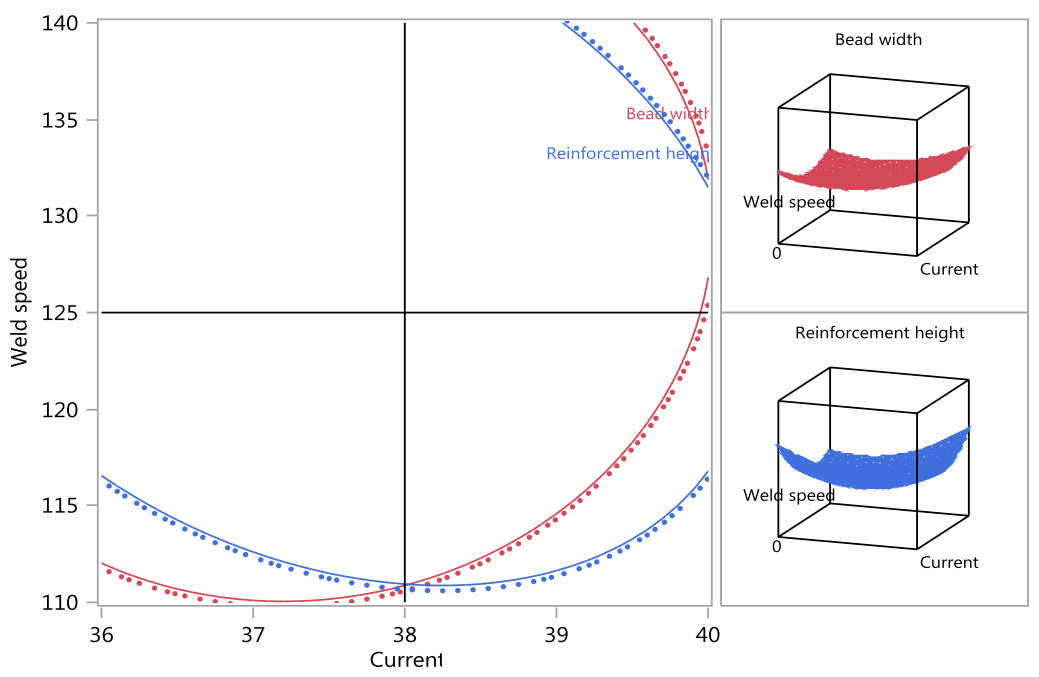

Fig. 4 Contour plots in terms of current, weld speed w.r.t responses; bead width, reinforcement height

\subsubsection{Response surface reports}

Response surface for the responses weld bead width and reinforcement height was developed to indicate the stationary points of responses considering the developed regression equations by developing the isosurface plots. An isosurface is a three dimensional representation of the three variables in $\mathrm{X}, \mathrm{Y}$ and $\mathrm{Z}$ axis, optimal point in space and predicted formula on surface. The second order model with square terms described by several shaped response surfaces. The input variable are presented in $\mathrm{X}$ and $\mathrm{Y}$ axis whereas response in Zaxis. The stationary point of the response surface can be minimum, maximum or saddle point (minimax). In this cases the solution is minimum for the both the responses weld bead width and reinforcement height. The predicted value at solution is weld bead width $5.8 \mathrm{~mm}$, reinforcement height $0.28 \mathrm{~mm}$. The isometric response surface plot of responses weld bead width, reinforcement height is shown below in fig. number 5 and 6 .

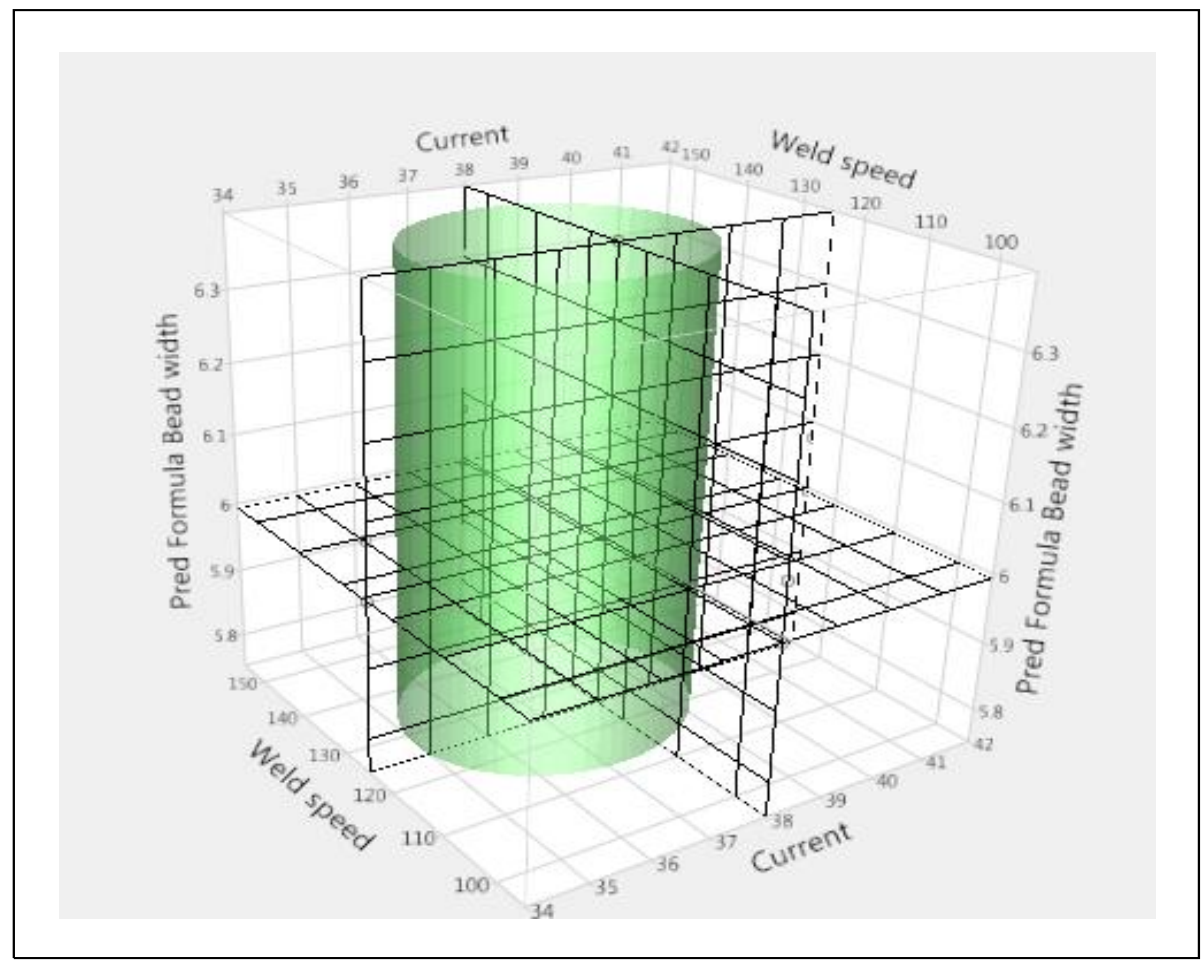

Fig. 5 Isosurface plot of response; weld bead width 


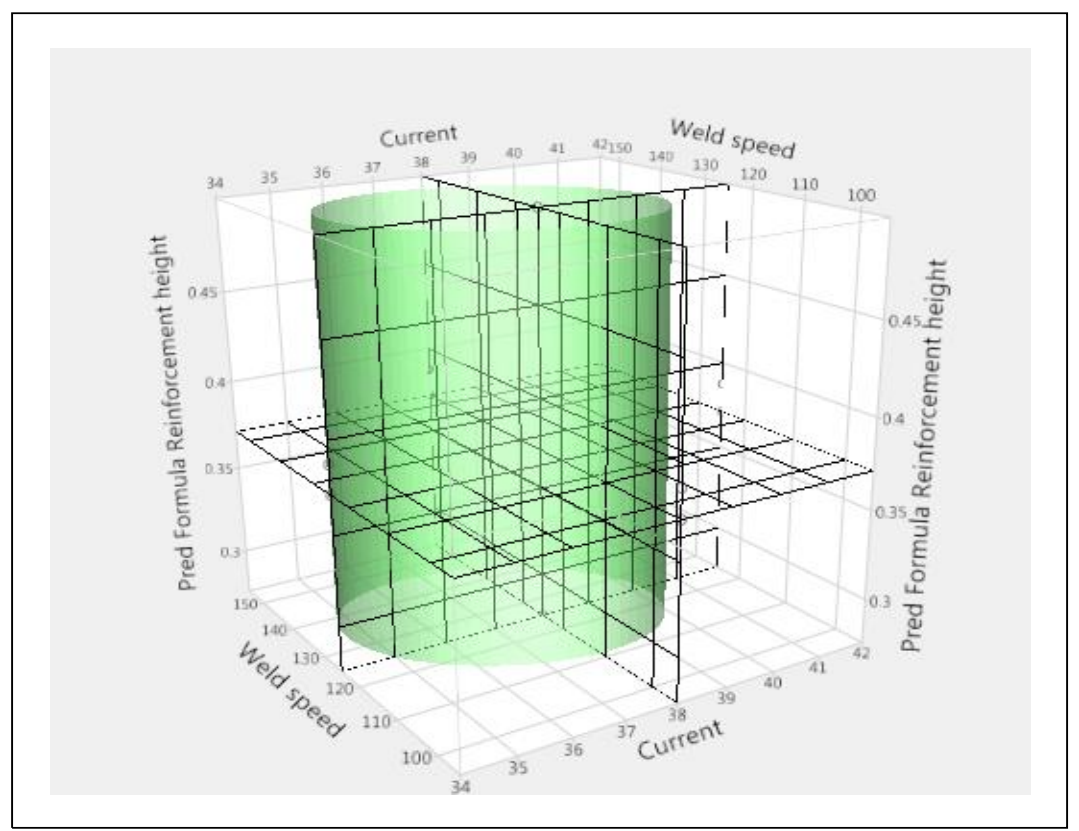

Fig. 6 Isosurface plot of response; reinforcement height

\section{Desirability function}

The desirability function is a transformation of the response variable to a 0 to 1 scale, a response of 0 indicates a completely undesirable response and 1 indicates the most desirable response. The desirability scale represented along the $\mathrm{X}$-axis and response along $\mathrm{Y}$-axis. The operating condition which satisfies this experiment is that is the lower is better (minimize). The desirability profile shown below in the fig. number 7 in which the desirability obtained is 0.849 which is much closer to 1 suggests that the responses weld bead width and reinforcement height is desirable. And the desirability shape indicates that the lower is better (minimize).

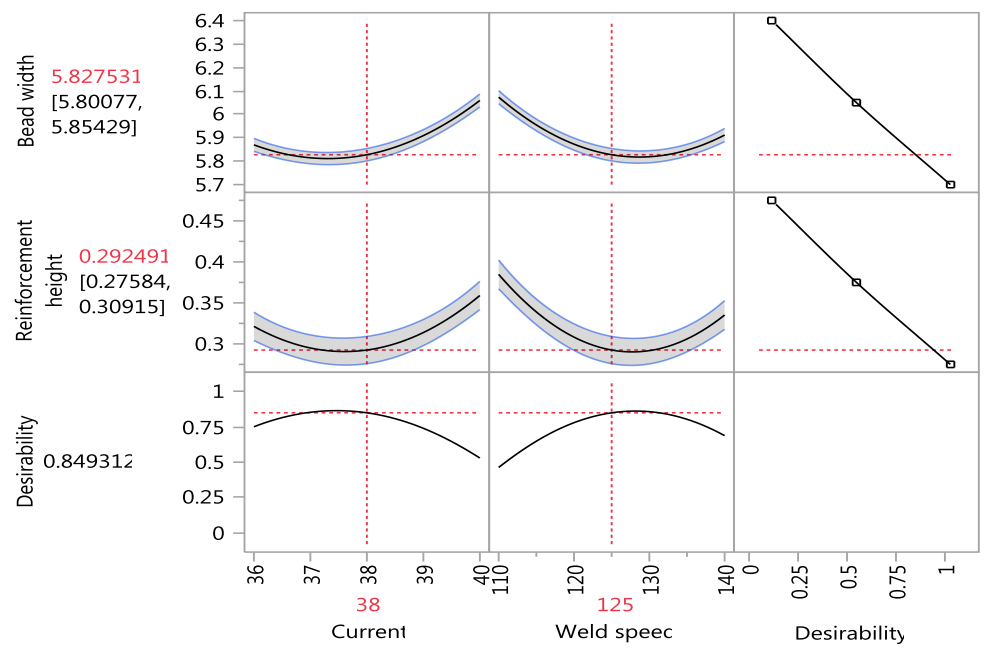

Fig. 7 Multiple response optimization - desirability profile

\section{Validation of the developed relationship}

The confirmatory experiment was conducted with the welding parameters as suggested by the response modeling. The suggested parameter is current 28Amps, welding speed $125 \mathrm{~mm} / \mathrm{min}$. The three replicate experiments was conducted with the optimized parameter, the weld bead width is reported $5.8 \mathrm{~mm}$, reinforcement height $0.28 \mathrm{~mm}$. The errors in prediction are shown below in table 11 . The process parameter having less error in prediction is considered as optimized parameter. The confirmation of the optimized parameters and obtained experimental outputs are tabulated below in table 12. The error between the experimental output and predicted values is up to accepted level so the model is a valid model and regression equation can be used for the prediction of the responses; weld bead width and reinforcement height. 
Multiple Response Optimization of TIG Welding Process for Optimum Weld Bead Width and ..

Table 11 Error in predictions report

\begin{tabular}{|c|c|c|c|c|c|c|c|c|}
\hline $\begin{array}{c}\text { SI. } \\
\text { no. }\end{array}$ & $\begin{array}{c}\text { Current } \\
\text { (Amps) }\end{array}$ & $\begin{array}{c}\text { Weld } \\
\text { speed } \\
(\mathbf{m m} / \mathbf{m i n})\end{array}$ & $\begin{array}{c}\text { Bead } \\
\text { width } \\
\mathbf{( m m})\end{array}$ & $\begin{array}{c}\text { Predicted } \\
\text { formula } \\
\text { Bead } \\
\text { width(mm) }\end{array}$ & $\begin{array}{c}\text { Error in } \\
\text { predicti } \\
\text { on }\end{array}$ & $\begin{array}{c}\text { Reinforc } \\
\text { ement } \\
\text { height } \\
\text { (mm) }\end{array}$ & $\begin{array}{c}\text { Predicted } \\
\text { formula } \\
\text { Reinforceme } \\
\text { nt height }\end{array}$ & $\begin{array}{c}\text { Error in } \\
\text { prediction }\end{array}$ \\
\hline 1 & 36 & 110 & 6.12 & 6.10 & 0.0171 & 0.44 & 0.44 & 0.0106 \\
\hline 2 & 36 & 140 & 5.97 & 5.96 & 0.0171 & 0.34 & 0.33 & 0.0106 \\
\hline 3 & 40 & 110 & 6.32 & 6.31 & 0.0171 & 0.41 & 0.41 & 0.0106 \\
\hline 4 & 40 & 140 & 6.11 & 6.12 & 0.0171 & 0.44 & 0.43 & 0.0106 \\
\hline 5 & 35 & 125 & 5.98 & 5.99 & 0.0178 & 0.37 & 0.37 & 0.011 \\
\hline 6 & 41 & 125 & 6.29 & 6.27 & 0.0178 & 0.43 & 0.42 & 0.011 \\
\hline 7 & 38 & 104 & 6.25 & 6.26 & 0.0171 & 0.47 & 0.45 & 0.0106 \\
\hline 8 & 38 & 146 & 6.05 & 6.03 & 0.0171 & 0.38 & 0.39 & 0.0106 \\
\hline 9 & 38 & 125 & 5.82 & 5.82 & 0.0109 & 0.3 & 0.29 & 0.006 \\
\hline 10 & 38 & 125 & 5.85 & 5.82 & 0.0109 & 0.28 & 0.29 & 0.006 \\
\hline 11 & 38 & 125 & 5.84 & 5.82 & 0.0109 & 0.31 & 0.29 & 0.006 \\
\hline 12 & 38 & 125 & 5.8 & 5.82 & 0.0109 & 0.28 & 0.29 & 0.006 \\
\hline
\end{tabular}

Table 12 Conformance of optimized parameter

Current - 36Amps Welding speed - 125mm/min

By experiment measured weld bead width $-5.8 \mathrm{~mm}$

By predicted model weld bead width $-5.85 \mathrm{~mm}$ Error in prediction $-0.86 \%$

By experiment measured reinforcement height $-0.28 \mathrm{~mm}$

By predicted model reinforcement height $-0.31 \mathrm{~mm}$ Error in prediction $-10.71 \%$

\section{Conclusion}

An empirical relationship was developed to predict the weld bead width and reinforcement height of tungsten inert gas welded Ti-6Al-4V titanium alloy using response surface methodology. The developed relationship can be effectively used to predict the weld bead width, reinforcement height of tungsten inert gas welded joints at $95 \%$ confidence level. The multiple response optimization technique called desirability function was used in this investigation and found to be 0.849 much closer to 1 , which indicates that the responses taken for the investigation are valid and the predicted model fits the experimental data well. The optimized values are current $38 \mathrm{Amps}$ and welding speed $125 \mathrm{~mm} / \mathrm{min}$. The obtained weld bead width is $5.8 \mathrm{~mm}$ and reinforcement height is $0.28 \mathrm{~mm}$. As the error between the prediction and experiment is in acceptable level therefore the model is a valid model. Current and welding speed both has the individual effects on the responses; weld bead width and reinforcement height.

\section{References}

[1]. Khanna O. P. A textbook of welding technology $19^{\text {th }}$ edition (2010), Dhanpat rai publications (P) Ltd, New Delhi.

[2]. Davies A.C., The Science and practice of welding volume $1 \& 2,8^{\text {th }}$ edition, (1984), Cambridge University press Cambridge, London.

[3]. Montgomery D. C., Design and Analysis of Experiments, $3^{\text {rd }}$ edition (1991), John Wiley \$ Sons, New York USA.

[4]. Ross J. Phillip, Taguchi techniques for quality Engineering, $2^{\text {nd }}$ edition, TATA McGraw-Hill, New Delhi.

[5]. Daniel J. Obermiller, Multiple Response Optimization using JMP, The Dow chemical company, Midland, MI.

[6]. Robert L. Mason, Richard F. Gunst, James L. Hess, Statistical Design and Analysis of Experiments With Applications to Engineering and Science, Second Edition, 2003 by John Wiley \& Sons, Inc., Hoboken, New Jersey.

[7]. Kundan Kumar, Chattopadhyaya Somnath, Yadav Avadhesh, Surface response methodology for predicting the output responses of TIG welding process, Asian Journal of Engineering Research, ISSN-2319-2100.

[8]. Kiaee N, Aghaie-Khafri M, Optimization of gas tungsten arc welding process by response surface methodology, Materials and Design 54 (2014) 25-31. www.elsevier.com/locate/matdes.

[9]. Balasubramanian M., Jayabalan V., Balasubramanian V., Effect of process parameters of pulsed current tungsten inert gas welding on weld pool geometry of titanium welds, ACTA metallurgical sinica, August 2010.

[10]. Q. Wang, D.L. Sun, Y. Na. Y. Zhou, X.L. Han, J. Wang, Effects of TIG welding parameters on morphology and mechanical properties of welded joint of Ni-base superalloy, School of Materials Science and Engineering, Harbin Institute of Technology, Harbin, China.

[11]. Kondapali S. P., Chalamalasetti S. R., Damera N. R., Application of Taguchi based design of experiments to Fusion Arc weld process: A review, International Journal of Technology and Management, ISSN 1927-9000, Vol. 2 No. 1, pp. 1-8 (2013).

[12]. Balasubramanian M., Prediction of optimum weld pool geometry of PCTIG welded titanium alloy using statistical design, Elsevier - Engineering Science and Technology, an International journal (2015). 
[13]. E. Rodrfguez-carmona, A. Manresa, J. Bastida, Application of experimental design and canonical analysis of response surfaces to the optimization of poly (3-hydroxyalkanoates) production by Pseudomonas aeruginosa 42A2. Chemical and Biomedical Engineering quarterly 27(4): 457-465 December 2013.

[14]. Singh Ravinder Pal, Garg R.K., Shukla Dinesh Kumar, Mathematical modeling of effect of polarity on weld bead geometry in submerged arc welding, Elsevier - Journal of Manufacturing process 21 (2016) 14-22.

[15]. Edwin Raja Dhas J a, Jenkins Hexley Dhas S, International Conference on Modeling, Optimization and Computing, "A review on optimization of welding process", Elsevier - Procedia Engineering 38 (2012) 544-554.

[16]. Sivarao, Shukor, T.J.S. Anand and Ammar, DOE based statistical approaches in Modeling of Laser processing review and suggestion, International journal of Engineering \& Technology, IJET-IJENS, Vol: 10 No: 04.

[17]. Norrish John, Advanced welding processes technology and process control 2006, Woodhead publishing limited, The institute of Materials \& Mining, Cambridge, England.

[18]. Mannion Bernard, Heinzman Jack, "Determining parameters for GTAW" starting point for success, July/august 1999 issue of practical welding today, Elderfield \& Hall/Pro-Fusion 222N. Maplewood Ave. Chicago, IL 60612. 